\title{
Alopecia Areata. Current situation and perspectives
}

\author{
Karina J. Juárez-Rendón, M.D. ${ }^{a}$, Gildardo Rivera Sánchez, M.D. ${ }^{b}$, \\ Miguel Á. Reyes-López, M.D. ${ }^{b}$, José E. García-Ortiz, M.D. ${ }^{c}$, Virgilio Bocanegra-García, M.D. ${ }^{b}$, \\ Iliana Guardiola-Avila, M.D. ${ }^{a}$ and María L. Altamirano-García, M.D. ${ }^{d}$
}

\begin{abstract}
Alopecia areata (AA) is a dermatological disease characterized by non-scarring hair loss of the scalp and/or body, with an unpredictable and variable evolution in the patients in which, despite multidisciplinary efforts, its etiology is not entirely known, although some evidence suggests that environmental, immunological and genetic factors could be generating the disease. The aim of this review is to provide an updated panorama of the clinical characteristics, diagnosis and treatment of AA, to analyze the mechanisms that could participate in its etiology, as well as to review some of the most important genetic variants that could confer susceptibility to the development of this disease.

Key words: Alopecia Areata, genes, susceptibility.
\end{abstract}

a. CONACYT Research

Fellow - Centro

de Biotecnología

Genómica, Instituto

Politécnico Nacional.

Reynosa, Tamaulipas, México.

b. Centro de

Biotecnología

Genómica, Instituto

Politécnico Nacional.

Reynosa, Tamaulipas,

México.

c. División de

Genética, Centro

de Investigación

Biomédica de

Occidente, Centro

Médico Nacional de

Occidente, Instituto

Mexicano del Seguro

Social, Guadalajara,

Jalisco, México.

d. Centro

Dermatológico

Brunnenhalt de

Reynosa. Reynosa,

Tamaulipas, México.

E-mail address:

Karina J. Juárez-Rendón,

M.D.:

kjgenetic2012@gmail.com

Funding:

None.

Conflict of interest:

None.

Received: 1-6-2017

Accepted: 5-21-2017 http:/ / dx.doi.org/10.5546/ aap.2017.eng.e404

To cite: Juárez-Rendón KJ, Rivera Sánchez G, ReyesLópez MÁ, et al. Alopecia Areata. Current situation and perspectives. Arch Argent Pediatr 2017;115(6):e404-e411.

\section{INTRODUCTION}

Alopecia is a common finding, although in some cases it can be associated with other diseases. ${ }^{1,2}$ One example is alopecia areata (AA) (OMIM 104000), which is characterized by non-scarring hair loss. ${ }^{3}$ It has a variable and unpredictable evolution in each patient ${ }^{4}$ and is classified into the following three groups according to severity and the areas where hair loss is observed: 1) alopecia areata in patches (AA), considered the most common form and identified by round or oval patches on the head (90\% of cases) or in different parts of the body; 2) alopecia totalis (AT), in which there is a complete or almost complete absence of hair on the scalp; and 3) alopecia universalis (AU), established as the most severe and differentiated from the previous two because the total loss of hair is observed all over the body in addition to the face and scalp. ${ }^{5,6}$

\section{Epidemiology}

Diverse studies have established that AA affects $1-2 \%$ of the general population with an estimated lifetime risk of $1.7 \%{ }^{7,8}$ However, prevalence can vary between 0.1 and $6.9 \%$ depending on the population studied. ${ }^{9}$ In the United States, AA affects 0.7 to $3 \%$ of its population. In the United Kingdom, approximately $2 \%$ of the population presents this disease. ${ }^{10}$ In Mexico, the reported prevalence is between 0.2 to $3.8 \%{ }^{11}$; in Korea, it has been estimated that AA affects between 0.9 and $6.9 \%$ of individuals. ${ }^{12}$

AA does not distinguish genders, although some reports suggest a slight predominance in women. ${ }^{3,13}$ However, this can depend on the population studied, since in countries like India and Turkey, the majority of cases correspond to men ${ }^{14}$ with these presenting the most severe forms in comparison to women $(63 \%$ vs. $36 \%$ respectively). ${ }^{15}$ On the other hand, it has been established that AA affects all age groups ${ }^{16}$, although approximately $25 \%$ of the individuals are children. ${ }^{17} \mathrm{AA}$ in neonates occurs less frequently and according to the literature, the condition may appear in the first months of life. ${ }^{18,19}$

The age range in which $\mathrm{AA}$ is presented, is between 4-5 years and 15-40 years of age, with a higher prevalence between 10 and 25 years $(60 \%)$. Nevertheless, recent studies report that $1-2 \%$ of individuals younger than 2 years and $21-24 \%$ under 16 years, are affected. AA rarely occurs in adults greater than 60 years. ${ }^{9,13,20}$

\section{Etiology}

The basic structure of the hair follicle is considered the most complicated and important annexes 
of the skin. Its functions include protecting the skin from ultraviolet radiation, suppression of heat loss, and touch sensation. ${ }^{3}$ The follicle passes through three phases during a normal growth cycle: anagen, catagen and telogen. The anagen phase is considered the growth phase (approximately $1 \mathrm{~cm}$ per month) and thus it is the longest (2-6 years). ${ }^{7}$ In the catagen phase (2-4 weeks), hair growth is interrupted, i.e., a process of keratinocyte apoptosis occurs; in addition, there is preparation for the last phase of the cycle. ${ }^{3}$ The telogen phase (2-3 months) is characterized by a stage of inactivity in which the hair is gradually lost before beginning a new growth cycle. ${ }^{21}$ However, in patients with AA, hair loss could be due to an alteration of one of these follicle growth phases, in other words, a premature transition from the anagen to the catagen ${ }^{2}$ or the anagen to telogen phase could happen. ${ }^{7}$. Since this event cannot occur alone, several reports have suggested that despite the fact that the etiology of AA is not well known, it is possible that environmental, immunologic and genetic factors are responsible for its development. ${ }^{22,23}$

\section{Environmental factors}

With regard to the environment, has been proposed that stress could be one of the factors that could contribute to the development of AA.

FIGURE 1. Phases of hair follicle growth.

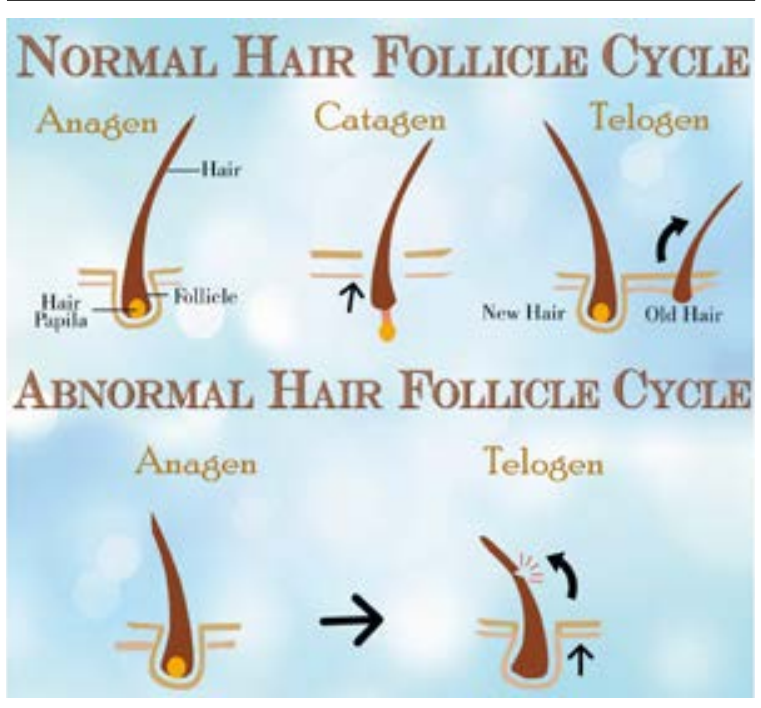

Normal growth cycle of hair follicle and one of the alterations that could occur during the phases in individuals with AA.
Studies have reported that at least $23 \%$ of patients have had an emotional event or an identity crisis before the onset of AA. ${ }^{11,24,25}$ Other factors such as infections, toxins and even food, could be associated with immune dysregulation processes and thus have been proposed as possible triggers of the disease, although not all have been validated. ${ }^{13,15}$

\section{Immunological factors}

Several research groups have reported that AA has a strong association with autoimmune diseases such as vitiligo. It has been estimated that a patient with AA has a two times greater probability of having vitiligo than the general population. Patients with AT and AU also have a higher risk, while individuals who already have vitiligo have a four times greater risk of developing AA. ${ }^{26}$ It has been observed that $2.3 \%$ of patients with thyroid disease, $3.2 \%$ of patients with type 1 diabetes mellitus, $0.9 \%$ with rheumatoid arthritis, $10-60 \%$ with pernicious anemia and $4.1 \%$ of patients with vitiligo, may develop AA, ${ }^{14,27}$ although Addison's disease, systemic lupus erythematosus, myasthenia gravis, scleroderma, allergic rhinitis, atopic dermatitis, asthma ${ }^{24}$ and psoriasis, ${ }^{28}$ have also been associated, therefore, a positive history of autoimmune diseases, could represent a group of patients with AA. ${ }^{10}$

In addition to this, it has been hypothesized that AA is caused because patients develop antibodies that affect the structure of their own hair follicles in the anagen phase, specifically, CD4+ and CD8+ T lymphocytes infiltrate the bulb of the hair follicle. ${ }^{13,29} \mathrm{CD} 8+$ lymphocytes are mainly responsible for follicular damage and predominate during activation of the disease, while CD4+ lymphocytes are fewer and only contribute together with CD8+ cells in the development of AA. Although It has been proposed that not only CD4+ and CD8+ lymphocytes are involved in these processes but also, natural killer cells, macrophages, Langerhans cells, and cytokines, ${ }^{30,31}$ which could be generating three events: 1) an inflammatory process at the periphery of the patches, 2) an alteration of the hair follicle cycles, and 3) growth inhibition. ${ }^{29}$

\section{Genetic factors}

Most cases of AA are sporadic. ${ }^{32}$ However, there are reports that mention a strong association between genetics factors and development of the disease, ${ }^{9}$ supported by three types of 
studies: 1) family-based linkage, 2) studies in monozygotic twins, in which a concordance of $50 \%$ of developing the disease has been observed, ${ }^{14}$ and 3) studies based on heritability in first-degree relatives, ${ }^{10}$ in which a positive family incidence of 10 to $42 \%$ for AA has been reported. ${ }^{16}$ Three percent of patients have at least one brother with the disease and $2 \%$ have at least one affected child, ${ }^{10}$ with an estimated risk of $6 \%$, in children of patients with AA. ${ }^{13}$

On the other hand, it has been found that AA has a polygenic origin, in other words, it does not follow a common Mendelian pattern that can be attributed to a single gene locus; therefore, multiple genes intervene causing a greater susceptibility to developing the disease. ${ }^{9}$ For this reason, in recent years, association studies of candidate genes for AA have been developed ${ }^{27}$ and these genes have been mostly selected according to the following characteristics: 1) they participate in inflammatory processes, 2) they are immune-regulatory genes, and 3) they regulate the differentiation and maintain $T$ cells. ${ }^{24,28}$ Starting with these characteristics, genes with specific functions in the hair follicle such as STX17, PRDX5, ULBP6 and ULBP3, genes associated with inflammatory processes or the immune response, such as $H L A, N O C H 4, M I C A$, IL-13, IL-4, PTPN2, IRG, IFN, NKG2D, IKZF4, CTLA4, as well as the genes shown in Annex 1, have been analyzed in diverse studies, although the results have been variable depending on the population studied. ${ }^{33}$

\section{Clinical manifestations}

Patchy AA is the most common form in children. It is characterized by the presence of circular or oval areas of non-scarring hair loss, on the scalp, eyebrows, eyelashes or any other place where there is hair. ${ }^{20} \mathrm{In}$ adults, in addition to the mentioned areas, patches can also be observed in the beard or in the pubic area and the size and number can be variable in each patient. ${ }^{21}$ In more severe cases such as AT or AU, the almost complete loss of hair on the scalp or face and the entire body are respectively evident. ${ }^{5}$

\section{Diagnosis}

Obtaining an accurate diagnosis in patients with AA can be at times complex, particularly in newborns given the little hair they have at this stage. ${ }^{1,20}$ For this reason, the diagnosis should be based on clinical history and physical examination. ${ }^{34}$ The clinical history is one of the key elements to identify possible triggers of the disease or provides evidence to determine the presence of another clinical disorder. ${ }^{2}$ The physical examination will allow to establish an accurate diagnosis, with the support of techniques like the hair pull test and the Jacquet's sign. Also, using dermatoscopy, small yellow spots and exclamation point hairs -short, broken off, distally wide hairs approximately 3 to $4 \mathrm{~mm}$ long- can be seen at the periphery of the patch, although this characteristic is only seen in cases of simple AA. ${ }^{2,21,35}$

The nails and appearance of the hair should be considered during physical examination. It has been reported that 10 to $66 \%$ of patients with AA present pitting ungueal among the most common, ${ }^{2,10,25}$ while white, thin, shine-less hair can be seen in some patients. ${ }^{35}$

Histological examination although are not necessarily essential for the diagnosis of AA, could be useful in particular cases, since they allow the observation of cell aggregates around the hair bulb, which are responsible for the inflammatory processes. ${ }^{54}$ On the other hand, laboratory tests are indicated in those cases where associated autoimmune conditions exist. ${ }^{35}$

The differential diagnosis should also be considered to establish a precise diagnosis in patients with AA. In children, it is mainly performed with trichotillomania and tinea capitis, congenital triangular alopecia and transient neonatal hair $\operatorname{loss}^{20}$ and in both in children and adults, telogen effluvium and traction alopecia should be considered. Lupus erythematosus and androgenic alopecia are of greater interest in adults. ${ }^{55,56}$

\section{Treatment}

AA is not easily treated, and unfortunately, no universal totally accepted treatment exists for all cases. However, British and Japanese treatment guidelines for AA have suggested topical immunotherapy (dinitrochlorobenzene, diphenylcyclopropenone o el squaric acid dibutylester) as one of the most effective options, ${ }^{7,8}$ although intralesional, topical or systemic corticosteroids (fluocinolone acetonide, triamcinolone acetonide, dexamethasone, clobetasol propionate and methylprednisolone), are used in patients with AA. 10,14

Other treatment options include anthralin, azathioprine, ${ }^{10}$ cyclosporine, methotrexate, sulfasalazine, minoxidil, ${ }^{21}$ adalimumab, ${ }^{29}$ tofacitinib and ruxolitinib. ${ }^{57,58}$ All of which are 
oriented towards eliminating inflammation, preventing hair loss, and controlling symptoms. ${ }^{2}$. It is important to point out that patients under treatment with these drugs should be constantly clinically monitored due to the adverse effects that can be generated such as weight gain, avascular necrosis, hypertension, diabetes, sleep disturbances, mood changes, acne, sensitivity to allergies ${ }^{21}$, atypical hair coloration ${ }^{59}$ or even diseases such as vitiligo, which can be caused by diphenylcyclopropenone. ${ }^{26}$

Despite the different treatment options for AA, it is clear that each individual responds differently to the drug and the disease; ${ }^{29}$ examples of this are cases of severe AA, in which the response to any drug could depend on a set of factors, such as age at start of onset, patient age, family history, in addition to the clinical conditions that could be associated. ${ }^{24}$

In children, treatment options are very limited given the adverse effects generated. Therefore, drugs with minor adverse effects should be prescribed, considering that the majority of the cases in this age group are of spontaneous remission. ${ }^{60}$ For patchy A A cases, topical corticosteroids such as $0.05 \%$ betamethasone dipropionate, $0.05 \%$ clobetasol propionate, or $0.1 \%$ triamcinolone acetonide, may be used for 3 to 4 months. Intralesional corticosteroids in children are not tolerated and should be avoided. ${ }^{25,61}$ However, both 5\% minoxidil and $1-2 \%$ topical antraline could be prescribed in these patients. ${ }^{62}$ In severe cases of AA, topical immunotherapy (diphenylcyclopropenone), has been used. Although corticosteroid pulse therapy has shown lower adverse effects at low doses. ${ }^{63,64}$ Methotrexate is being evaluated in children with AT or AU and prednisolone has been recommended in some cases..$^{63,65}$

\section{Prognosis}

The course of AA in both children and adults is unpredictable. However, it has been established that a poor prognosis could be due to the early age of onset, the extent of hair loss, nail abnormalities, a positive family history for AA and comorbidity with autoimmune diseases. ${ }^{21}$ Severe cases occur more frequently before puberty and have less than a $10 \%$ chance of regaining hair despite treatments. ${ }^{63}$

\section{Psychological management}

Hair loss in children and adults has important psychological effects not only in affected patients but also in families given the cosmetic effect it causes. Low self-esteem, anxiety, depression and negative effects on their quality of life, are some examples. ${ }^{57,66}$ In children, such effects could impact on their growth and development. ${ }^{20,64}$ Therefore, the patient with AA should receive both medical and psychological counseling. The Physician should explain to the patient or patient's parents (when they are children), the unpredictable nature of the condition, the possible course, the treatments available and the success or failure that these may have. Mental health specialists must work with the patient in managing emotions and providing emotional support in cases of relapse. ${ }^{66}$

\section{CONCLUSION}

AA is an increasingly common disease in individuals, which has significant emotional effects in children and adults. At present, there are no universal treatments that guarantee low rates of relapse and minor adverse effects. Therefore, it is necessary that new drugs be developed, from genes (therapeutic targets) that participate in autoimmune or inflammatory processes and in the development or function of the hair follicle.

\section{REFERENCES}

1. Wohltmann WE, Sperling L. Histopathologic diagnosis of multifactorial alopecia. J Cutan Pathol 2016;43(6):483-91.

2. Nalluri R, Harries M. Alopecia in general medicine. Clin Med (Lond) 2016;16(1):74-8.

3. Qi J, Garza LA. An overview of alopecias. Cold Spring Harb Perspect Med 2014;4(3):a013615.

4. Betz RC, Petukhova L, Ripke S, et al. Genome-wide metaanalysis in alopecia areata resolves HLA associations and reveals two new susceptibility loci. Nat Commun 2015;6:5966.

5. Rencz F, Gulácsi L, Péntek M, et al. Alopecia areata and health-related quality of life: a systematic review and metaanalysis. Br J Dermatol 2016;175(3):561-71.

6. Haida Y, Ikeda S, Takagi A, et al. Association analysis of the HLA-C gene in Japanese alopecia areata. Immunogenetics 2013;65(7):553-7.

7. Wolff H, Fischer TW, Blume-Peytavi U. The Diagnosis and Treatment of Hair and Scalp Diseases. Dtsch Arztebl Int 2016;113(21):377-86.

8. Yoshimasu T, Furukawa F2. Modified immunotherapy for alopecia areata. Autoimmun Rev 2016;15(7):664-7.

9. Salinas-Santander M, Sánchez-Domínguez C, CantúSalinas C, et al. Association between PTPN22 C1858T polymorphism and alopecia areata risk. Exp Ther Med 2015;10(5):1953-8.

10. Islam N, Leung PS, Huntley AC, et al. The autoimmunebasis of alopecia areata: A comprehensive review. Autoimmun Rev 2015;14(2):81-9.

11. Olguín García MG, Martín del Campo A, Rodríguez Acar $\mathrm{M}$, et al. Factores psicológicos asociados con la alopecia areata. Dermatol Rev Mex 2013;57(3):171-7.

12. Kim SK, Chung JH, Park HJ, et al. Polymorphisms in the 
promoter regions of the CXCL1 and CXCL2 genes contribute to increased risk of alopecia areata in the Korean population. Genet Mol Res 2015;14(3):9667-74.

13. Kim SK, Park HJ, Chung JH, et al. Association between interleukin 18 polymorphisms and alopecia areata in Koreans. J Interferon Cytokine Res 2014;34(5):349-53.

14. Ranawaka RR. An observational study of alopecia areata in Sri Lankan adult patients. Ceylon Med J 2014;59(4):128-31.

15. Alzolibani AA. Epidemiologic and genetic characteristics of alopecia areata (part 1). Acta Dermatovenerol Alp Pannonica Adriat 2011;20(4):191-8.

16. Aytekin $\mathrm{N}$, Akcali $\mathrm{C}$, Pehlivan $\mathrm{S}$, et al. Investigation of interleukin-12, interleukin-17 and interleukin-23 receptor gene polymorphisms in alopecia areata. J Int Med Res 2015;43(4):526-34.

17. Nageswaramma S, Lakshmi Sarojini V, Vani T, et al. A clinico-epidemiological study of pediatric hair disorders. Indian J Paedr Dermatol 2017;18(2):100-3.

18. Bonifazi E. Neonatal Alopecia Areata. Eur J Pediatr Dermatol 2011;21:56.

19. Lopera A, Gómez L, Trujillo M. Alopecia areata neonatal tratada con tacrolimus tópico: reporte de un caso. Rev Asoc Colomb Dermatol Cir Dermatol 2010;18(3):169-71.

20. Alves R, Grimalt R. Hair loss in children. Curr Probl Dermatol 2015;47:55-66.

21. Spano F, Donovan JC. Alopecia areata: Part 1: pathogenesis, diagnosis, and prognosis. Can Fam Physician 2015;61(9):751-5.

22. Kalkan G, Seçkin HY, Benli İ, et al. Relationship between manganese superoxide dismutase (MnSODAla-9Val) and glutathione peroxidase (GPx1 Pro $197 \mathrm{Leu}$ ) gene polymorphisms and alopecia areata. Int J Clin Exp Med 2015;8(11):21533-40.

23. Bhanusali DG, Sachdev A, Olson MA, et al. PTPN22 profile indicates a novel risk group in Alopecia areata. Hum Immunol 2014;75(1):81-7.

24. Hordinsky MK. Overview of alopecia areata. J Investig Dermatol Symp Proc 2013;16(1):S13-5.

25. Messenger A. Patient education: Alopecia areata (Beyond the Basics). UpToDate [Acceso: marzo de 2017] Disponible en: https: / / www.uptodate.com/ contents / alopeciaareata-beyond-the-basics

26. Riad H, Mannai HA, Mansour K, et al. Diphenylcyclopropenone-induced vitiligo in a patient with alopecia universalis. Case Rep Dermatol 2013;5(2):225-31.

27. Lu D, Chen L, Shi X, et al. A functional polymorphism in interleukin-1 $\alpha$ (IL1A) gene is associated with risk of alopecia areata in Chinese populations. Gene 2013;521(2):282-6.

28. MegiorniF, Mora B, Maxia C, et al. Cytotoxic T-lymphocyte antigen 4 (CTLA4) +49AG and CT60 gene polymorphisms in Alopecia Areata: a case-control association study in the Italian population. Arch Dermatol Res 2013;305(7):665-70.

29. Gorcey L, GordonSprattEA, Leger MC. Alopecia universalis successfully treated with adalimumab. JAMA Dermatol 2014;150(12):1341-4.

30. Kalkan G, Karakus N, Baş Y, et al. The association between Interleukin (IL)-4 gene intron 3 VNTR polymorphism and alopecia areata (AA) in Turkish population. Gene 2013;527(2):565-9.

31. Seok H, Suh DW, Jo B, et al. Association between TLR1 polymorphisms and alopecia areata. Autoimmunity 2014;47(6):372-7.

32. Alzolibani AA, Zari S, Ahmed AA. Epidemiologic and genetic characteristics of alopecia areata (part 2). Acta Dermatovenerol Alp Pannonica Adriat 2012;21(1):15-9.

33. Norris DA. Genes and immune response in alopecia areata: review of the alopecia areata research summit first day proceedings. J Investig Dermatol Symp Proc 2013;16(1):S10-2. 34. Pratt CH, King LE Jr, Messenger AG, et al. Alopecia areata.
Nat Rev Dis Primers 2017;3:17011.

35. Restrepo R, Niño L. Alopecia areata, nuevos hallazgos en histopatología y fisiopatología. Rev Asoc Colomb Dermatol Cir Dermatol 2012;20(1):41-53.

36. Wengraf DA, McDonagh AJ, Lovewell TR, et al. Genetic analysis of autoimmune regulator haplotypes in alopecia areata. Tissue Antigens 2008;71(3):206-12.

37. Tazi-Ahnini R, Cork MJ, Gawkrodger DJ, et al. Role of the autoimmune regulator (AIRE) gene in alopecia areata: strong association of a potentially functional AIRE polymorphism with alopecia universalis. Tissue Antigens 2002;60(6):489-95.

38. Jan A, BasitS, WakilSM, et al. A novel homozygous variant in the $d s p$ gene underlies the first case of non-syndromic form of alopecia. Arch Dermatol Res 2015;307(9):793-801.

39. Alfadhli S, Kharrat NJ, Al-Tememy B, et al. Susceptible and protective endothelial nitric oxide synthase gene polymorphism in alopecia areata in the Kuwaiti population. Autoimmunity 2008;41(7):522-5.

40. Kalkan G, Ateş O, Karakuş N, et al. Functional polymorphisms in cell death pathway genes FAS and FAS ligand and risk of alopecia areata. Arch Dermatol Res 2013;305(10):909-15.

41. Fan X, Shangguan L, Li M, etal. Functional polymorphisms of theFAS / FASLG genes are associated with risk of alopecia areata in a Chinese population: a case-control analysis. $\mathrm{Br}$ J Dermatol 2010;163(2):340-4.

42. Conteduca G, Rossi A, Megiorni F, et al. Single nucleotide polymorphisms in the promoter regions of Foxp3 and ICOSLG genes are associated with Alopecia areata. Clin Exp Med 2014;14(1):91-7.

43. Ahmed MS, Rauf S, Naeem M, et al. Identification of novel mutation in the HR gene responsible for atrichia with papular lesions in a Pakistani family. J Dermatol 2013;40(11):927-8.

44. Nucara S, Colao E, Mangone G, et al. Identification of a new mutation in the gene coding for hairless protein responsible for alopecia universalis: The importance of direct gene sequencing. Dermatol Online J 2011;17(1):3.

45. Alfadhli S, Nanda A. Genetic analysis of interleukin-1 receptor antagonist and interleukin- $1 \beta$ single-nucleotide polymorphisms C-511T and C+3953T in alopecia areata: susceptibility and severity association. Clin Exp Med 2014;14(2):197-202.

46. KalkanG, YigitS,KarakuşN, etal.Methylenetetrahydrofolate reductase $\mathrm{C} 677 \mathrm{~T}$ mutation in patients with alopecia areata in Turkish population. Gene 2013;530(1):109-12.

47. AlfadhliS, Nanda A. Genetic evidence for the involvement of NOTCH4 in rheumatoid arthritis and alopecia areata. Immunol Lett 2013;150(1-2):130-3.

48. Betz RC, König K, Flaquer A, et al. The R620W polymorphism in PTPN22 confers general susceptibility for the development of alopecia areata. $\mathrm{Br} J$ Dermatol 2008;158(2):389-91.

49. Cantú S, Salinas M, Lagos A, et al. Tumor necrosis factor alpha promoter-308G/A polymorphism in Mexican patients with patchy alopecia areata. Int J Dermatol 2012;51(5):571-5.

50. Miao Y, Kang Z, Xu F, et al. Association analysis of the IL2RA gene with alopecia areata in a Chinese population. Dermatology 2013;227(4):299-304.

51. Redler S, Albert F, Brockschmidt FF, et al. Investigation of selected cytokine genes suggests that IL2RA and the TNF / LTA locus are risk factors for severe alopecia areata. $\mathrm{Br} \mathrm{J}$ Dermatol 2012;167(6):1360-5.

52. Lew BL, Chung JH, Sim WY. Association between IL16 gene polymorphisms and susceptibility to alopecia areata in the Korean population. Int J Dermatol 2014;53(3):319-22. 
53. Kim HK, Lee H, Lew BL, et al. Association between TAP1 gene polymorphisms and alopecia areata in a Korean population. Genet Mol Res 2015;14(4):18820-7.

54. Hordinsky MK. Treatment of alopecia areata: "What is new on the horizon?" Dermatol Ther 2011;24(3):364-8.

55. Messenger AG, McKillop J, Farrant P, et al. British Association of Dermatologists' guidelines for the management of alopecia areata 2012. Br J Dermatol 2012;166(5):916-26.

56. Alkhalifah A, Alsantali A, Wang E, et al. Alopecia areata update: part I. Clinical picture, histopathology, and pathogenesis. J Am Acad Dermatol 2010;62(2):177-88.

57. Craiglow BG, Tavares D, King BA. Topical Ruxolitinib for the Treatment of Alopecia Universalis. JAMA Dermatol 2016;152(4):490-1.

58. Castelo-Soccio L, Mcmahon P. Pediatric Dermatology. J Clin Aesthet Dermatol 2017;10(3):S8-15.

59. Delorenze LM, Gavazzoni-Dias MF, Teixeira MS, et al. ConcentricPolycyclicRegrowth Pattern in Alopecia Areata. Int J Trichology 2016;8(1):35-7.

60. Lorizzo M, Oranje AP. Current and future treatments of alopecia areata and trichotillomania in children. Expert Opin Pharmacother 2016;17(13):1767-73.

61. Spano F, Donovan JC. Alopecia areata: Part 2: treatment. Can Fam Physician 2015;61(9):757-61.

62. Özdemir M, Balevi A. Bilateral Half-Head Comparison of 1\% Anthralin Ointment in Children with Alopecia Areata. Pediatr Dermatol 2017;34(2):128-32.

63. Jahn-Bassler K, Bauer WM, Karlhofer F, et al. Sequential high- and low-dose systemic corticosteroid therapy for severe childhood alopecia areata. J Dtsch Dermatol Ges 2017;15(1):42-7.

64. LalosevicJ, Gajic-VeljicM, Bonaci-NikolicB, etal.Combined oral pulse and topical corticosteroid therapy for severe alopecia areata in children: a long-term follow-up study. Dermatol Ther 2015;28(5):309-17.

65. Anuset D, Perceau G, Bernard P, et al. Efficacy and Safety of Methotrexate Combined with Low- to Moderate-Dose Corticosteroids for Severe Alopecia Areata. Dermatology 2016;232(2):242-8.

66. Cortés G A, Mardones V F, Zemelman D V. Caracterización de las causas de alopecia infantil. Rev Chil Pediatr 2015;86(4):264-9. 


\section{Annex 1}

\section{Gene variants associated with alopecia areata.}

\begin{tabular}{|c|c|c|c|c|c|}
\hline Gene & Locus & Function & Gene & Population I & ference \\
\hline$A I R E$ & $21 q 22.3$ & $\begin{array}{l}\text { Responsible for regulating transcriptional activity. In animal models, } \\
\text { mutations in this gene are associated with a deficiency of the cell immune } \\
\text { response. In humans, it is associated with autoimmune polyendocrinopathy } \\
\text { candidiasis-ectodermal dystrophy syndrome (APECED) characterized by } \\
\text { candidiasis, Addison's disease, thyroid disease and other autoimmune } \\
\text { conditions. AA is common in these patients. }\end{array}$ & $7215 \mathrm{~T}>\mathrm{C}$ & Caucasian & 37 \\
\hline $\begin{array}{l}\text { CXCL1 } \\
\text { CXCL2 }\end{array}$ & $4 q 12-13$ & $\begin{array}{l}\text { Chemokines that play an important role in the development, homeostasis } \\
\text { and function of the immune system. In addition, they participate in the } \\
\text { recruitment and activation of leukocytes, and in the balance of } \\
\text { angiogenesis, angiostasis, and T lymphocyte regulation. }\end{array}$ & $\begin{array}{l}-429 \mathrm{C}>\mathrm{T} \\
(\text { Promoter }) \\
-264 \mathrm{~T}>\mathrm{C} \\
(\text { Promoter })\end{array}$ & Korean & 12 \\
\hline$D S P$ & $6 \mathrm{p} 25.1-\mathrm{p} 23$ & $\begin{array}{l}\text { Encodes desmoplakin, a protein that is important for desmosomes, whose } \\
\text { function is to mediate adhesion between cells. Alterations in this gene } \\
\text { may affect the sites where desmosomes are needed, such as the skin, } \\
\text { hair, nails and heart. }\end{array}$ & $\begin{array}{l}\text { 1493C }>\mathrm{T} \\
\text { (Exon 12) }\end{array}$ & Pakistani & 38 \\
\hline NOS3 & $7 q 36.1$ & $\begin{array}{l}\text { Synthesizes nitric oxide (NO) from L-arginine in immune and inflammator } \\
\text { responses by stimulation of proinflammatory cytokines such as IL-1 } \beta, \\
\text { INF- } \gamma \text {, and TNF- } \alpha \text {. It is expressed in skin melanocytes and keratinocytes } \\
\text { and it has been hypothesized that NOS3 expression in the hair follicle } \\
\text { can induce apoptosis in cases of AA. }\end{array}$ & $\begin{array}{l}\text { ory } \\
\text { 27pbVNTR } \\
\text { (Intron } 4)\end{array}$ & Kuwaiti & 39 \\
\hline FAS & $10 \mathrm{q} 24.1$ & $\begin{array}{l}\text { Cell surface receptor characterized by regulating growth, maintaining } \\
\text { homeostasis and participating in apoptosis in association with FASLG. } \\
\text { It is expressed in the hair follicle and polymorphisms in this gene have } \\
\text { been associated with autoimmune diseases such as systemic lupus } \\
\text { erythematosus, vitiligo, Sjogren's syndrome, and Guillan Barre syndrome. }\end{array}$ & $\begin{array}{l}-670 A>G \\
\text { (Promoter) } \\
\end{array}$ & Turkish & 40 \\
\hline FASLG & $1 q 23$ & $\begin{array}{l}\text { Together with its Fas receptor, it participates in signaling cascades involvec } \\
\text { in cell death (apoptosis). It is expressed in various immune cells such as } \\
\text { T cells and natural killer cells and also expresses in perifollicular infiltrates; } \\
\text { therefore, it is suggested that polymorphisms in this gene could } \\
\text { contribute to the development of AA. }\end{array}$ & $\begin{array}{l}\text { ed } \\
-124 \mathrm{~A}>\mathrm{G} \\
(\text { Promoter }) \\
-844 \mathrm{~T}>\mathrm{C} \\
\text { (Promoter) }\end{array}$ & Turkish & 40 \\
\hline FOXP3 & Xp11.23 & $\begin{array}{l}\text { Responsible for modulating the function and development of regulatory } \\
\text { T cells (Treg). Treg control the homeostasis of the immune system. } \\
\text { Polymorphisms in this gene have been associated to autoimmune } \\
\text { diseases such as type } 1 \text { diabetes and psoriasis. }\end{array}$ & $\begin{array}{l}-3675 G>A \\
\text { (Promoter) }\end{array}$ & Italian & 42 \\
\hline$H R$ & 8p21-p22 & $\begin{array}{l}\text { Belongs to the family of nuclear repressors co-repressors, which prevent } \\
\text { transcription in the absence of specific ligands. It acts as a co-repressor } \\
\text { of thyroid hormones and the vitamin D receptor (VDR), blocking } \\
\text { the function of keratinocytes. It is also a regulator of apoptosis in the } \\
\text { catagen phase and in the absence of this gene, hair follicles are } \\
\text { disintegrated and new hair cannot be formed. }\end{array}$ & $\begin{array}{l}854 \mathrm{G}>\mathrm{A} \\
(\text { Exon } 3) \\
\text { O75InsGGCC } \\
\text { (Exon 17) }\end{array}$ & Pakistani & 43 \\
\hline IL1B & $2 q 13-21$ & $\begin{array}{l}\text { Intervenes in the inflammatory response. Participates in processes such } \\
\text { as proliferation, differentiation and apoptosis. Its involvement in the } \\
\text { inhibition of hair growth in humans has been proposed and that } \\
\text { the polymorphisms in this gene may be responsible for the } \\
\text { susceptibility and severity in patients with AA. }\end{array}$ & $\begin{array}{l}-511 C>T \\
\text { (Promoter) }\end{array}$ & Kuwaiti & 45 \\
\hline IL17A & $6 \mathrm{p} 12.2$ & $\begin{array}{l}\text { Secreted by T cells and other inflammatory cells. Involved in the productio } \\
\text { of proinflammatory cytokines, chemokines, cell adhesion molecules and } \\
\text { growth factors. Its high expression has been observed in certain } \\
\text { autoimmune diseases such as systemic lupus erythematosus, asthma, } \\
\text { and inflammatory bowel disease. }\end{array}$ & $7488 \mathrm{~A}>\mathrm{G}$ & Turkish & 16 \\
\hline MTHF & 1p36.3 & $\begin{array}{l}\text { Folate metabolism regulatory enzyme with possible influence on DNA } \\
\text { methylation and nucleic acid synthesis. Alterations in this gene have been } \\
\text { associated with a decrease in enzyme activity and elevated homocysteine } \\
\text { levels in plasma, disrupting normal cellular function in various tissues. } \\
\text { It has been suggested as the gene responsible for some autoimmune } \\
\text { diseases. }\end{array}$ & $\begin{array}{l}677 \mathrm{C}>\mathrm{T} \\
(\text { Exon } 4)\end{array}$ & Turkish & 46 \\
\hline
\end{tabular}




\begin{tabular}{|c|c|c|c|c|c|}
\hline NOTCH4 & 6 p21.3 & $\begin{array}{l}\text { Belongs to the family of receptors involved in various cellular signaling } \\
\text { pathways; also in the differentiation and maturation of T cells, therefore, } \\
\text { it has been associated with autoimmune diseases. Involved in the } \\
\text { arrest of growth and differentiation of keratinocytes. }\end{array}$ & $\begin{array}{c}1297 \mathrm{C}>\mathrm{T} \\
(\text { Exon 3) } \\
3063 \mathrm{~A}>\mathrm{G} \\
(\text { Exon 5) }\end{array}$ & Kuwaiti & 47 \\
\hline PTPN22 & 1p13.2 & $\begin{array}{l}\text { It is expressed in immune cells. It is characterized by suppressing T cell } \\
\text { activation; therefore, it has been associated with various autoimmune } \\
\text { diseases such as rheumatoid arthritis, systemic lupus erythematosus, } \\
\text { diabetes, and Graves' disease. A probable relationship between AA and } \\
\text { this gene has been studied in several world populations. }\end{array}$ & $\begin{array}{r}1858 \mathrm{C}>\mathrm{T} \\
\mathrm{Ca} \\
\text { no } \\
\text { Nor } \\
\text { Bel }\end{array}$ & $\begin{array}{l}\text { Mexican } \\
\text { aucasian and } \\
\text { on-Caucasian } \\
\text { rth American } \\
\text { lgian-German }\end{array}$ & $\begin{array}{l}9 \\
23 \\
48\end{array}$ \\
\hline TNFA & $9 p 13-21$ & $\begin{array}{l}\text { Proinflammatory cytokine that is synthesized in epidermal keratinocytes } \\
\text { with other cytokines and characterized as an autoimmune modulator. } \\
\text { Altered TNF- } \alpha \text { levels can cause changes in normal hair follicle growth } \\
\text { and the polymorphisms in this gene represent a risk factor for various } \\
\text { autoimmune diseases such as rheumatoid arthritis, systemic lupus } \\
\text { erythematosus, Crohn's disease, and others. }\end{array}$ & $\begin{array}{l}-308 \mathrm{G}>\mathrm{A} \\
\text { (Promoter) }\end{array}$ & Mexican & 49 \\
\hline HSPA1B & 6 p21.3 & $\begin{array}{l}\text { Gene associated with inflammatory processes and autoimmune } \\
\text { diseases such as vitiligo. It is suggested that it could play an important } \\
\text { role in AA since in animal models, its expression has been correlated } \\
\text { with hair loss and immune reactions on the hair follicle in the } \\
\text { anagen phase. }\end{array}$ & rs6457452 & Korean & 31 \\
\hline$I L 1 A$ & $2 q 14$ & $\begin{array}{l}\text { Cytokine expressed in keratinocytes and in the epidermis. It participates } \\
\text { in inflammatory processes and is characterized by inducing hair loss } \\
\text { and inhibiting its growth. In patients with AA, high levels of this } \\
\text { cytokine have been observed; therefore, it could be a candidate } \\
\text { gene for AA. }\end{array}$ & rs3783553 & Chinese & 27 \\
\hline$I L 2 R A$ & 10p15.1 & $\begin{array}{l}\text { Cytokine highly expressed in regulatory T cells and CD4+ and CD25+. } \\
\text { It is important for immune homeostasis and suppression of } \\
\text { autoimmune responses. It has been associated with various diseases } \\
\text { such as Graves' disease and multiple sclerosis. Alterations in this gene } \\
\text { result in severe immunodeficiency with T cell infiltrates in some tissues. }\end{array}$ & $\begin{array}{l}\text { rs3118470 } \\
\text { rs706778 }\end{array}$ & $\begin{array}{l}\text { Chinese } \\
\text { German } \\
\text { and Belgian }\end{array}$ & 50 \\
\hline IL16 & $15 q 26.3$ & $\begin{array}{l}\text { T cell chemoattractant cytokine associated with autoimmune diseases } \\
\text { such as systemic lupus erythematosus. In patients with AA, high levels } \\
\text { of this cytokine have been observed compared to normal population. }\end{array}$ & rs11073001 & Korean & 52 \\
\hline IL18 & $11 q 22.2$ & $\begin{array}{l}\text { Pleiotropic proinflammatory cytokine produced by immune cells such } \\
\text { as monocytes, macrophages and Kupffer cells, whose function is to } \\
\text { regulate the innate and acquired immune response. High levels of these } \\
\text { cytokines have been observed in autoimmune diseases such as } \\
\text { rheumatoid arthritis and systemic lupus erythematosus. }\end{array}$ & $\begin{array}{l}\text { rs187238 } \\
\text { rs549908 }\end{array}$ & Korean & 13 \\
\hline TAP1 & 6 p21.3 & $\begin{array}{l}\text { Gene involved in the presentation of CD8+ lymphocytes. It has been } \\
\text { seen associated with autoimmune disorders. Polymorphisms in this } \\
\text { gene may affect antigen recognition and presentation, considering it } \\
\text { a candidate gene for AA. }\end{array}$ & rs2071480 & Korean & 53 \\
\hline
\end{tabular}

